\title{
MENINGKATKAN KETERAMPILAN MENULIS PUISI RAKYAT MELALUI MODEL PAMPER
}

\author{
Rusniyati Abdulrahman, Mira Mirnawati \\ SMP Negeri 3 Gorontalo \\ rusniaty@gmail.com \\ miramirnawati@ung.ac.id
}

Received: 25 November 2018; Revised: 1 Desember 2018; Accepted: 5 Desember 2018

\begin{abstract}
ABSTRAK
Permasalahan dalam penelitian ini apakah Keterampilan Menulis Puisi Rakyat Melalui Model PAMPER (Picture And Picture Media Gambar) di kelas VIIA SMP Negeri 3 Gorontalo dapat ditingkatkan? Adapun tujuan penelitian ini untuk meningkatkan keterampilan menulis puisi rakyat melalui model PAMPER (Picture And Picture Media Gambar). Hasil analisis data menunjukan ada peningkatan keterampilan siswa menulis puisi rakyat dari siklus ke siklus. Hal tersebut ditunjukan oleh hasil tindakan pada setiap siklus. Pada siklus I Dari jumlah 27 orang siswa yang dikenakan tindakan pada siklus I terlihat bahwa pada aspek penentuan tema dari 27 orang siswa hanya terdapat 16 orang siswa atau 59,26\% yang terampil. Sedangkan pada siklus II terjadi peningkatan yakni 25 orang siswa atau 92,59\% yang terampil. pada siklus I terlihat bahwa pada aspek pengumpulan kosakata terdapat 15 orang siswa atau 55,56\% yang terampil. Sedangkan pada siklus II terjadi peningkatan yakni 26 orang siswa atau $96.30 \%$ yang terampil. Pada aspek penilaian teknik penulisan terdapat 18 orang atau $66,67 \%$ yang terampil. Sedangkan pada siklus II terjadi peningkatan yakni 24 orang atau $88.89 \%$ yang terampil.
\end{abstract}

\section{PENDAHULUAN}

Proses kegiatan belajar mengajar Bahasa Indonesia yang dicapai para siswa masih terbatas pada ketuntasan yang diukur melalui UASBN (Ujian Akhir Sekolah Berstandar Nasional), ditandai dengan siswa lulus dalam mata pelajaran Bahasa Indonesia. Paradigma ini muncul akibat eksistensi UASBN tersebut identik tes objektif yang pada umumnya hanya memuat aspek pengetahuan, sehingga banyak siswa belum bisa menggunakan bahasa yang hakiki, baik bahasa secara reseptif dan secara reproduktif, yang disebut keterampilan berbahasa.

Keterampilan berbahasa erat kaitannya dengan proses berpikir yang mendasari bahasa. Bahasa seseorang mencerminkan pikirannya. Semakin cerah dan jelas pikiran seseorang semakin terampil seseorang berbahasa. Melatih keterampilan berbahasa berarti melatih keterampilan berpikir. Keterampilan berbahasa mencakup empat segi, yaitu menyimak, berbicara, membaca dan menulis. Keempatnya merupakan caturtunggal atau dengan kata lain saling berhubungan erat dan tidak bisa dipisahpisahkan. Kemampuan ini sangat diperlukan dalam proses belajar mengajar bidang studi bahasa Indonesia sehingga akan tercipta komunikasi antara guru, siswa, siswa 


$\begin{array}{ll}\text { Volume } & : 05 \\ \text { Nomor } & : 01 \\ \text { Bulan } & : \text { Januari } \\ \text { Tahun } & : 2019 \\ \text { http } & : \text { //ejurnal.pps.ung.ac.id/index.php/AKSARA/index }\end{array}$

dengan siswa. Komunikasi tersebut hendaknya bersifat interaktif edukatif dan timbal balik yang harus dicapai oleh guru dan siswa. Dari keempat keterampilan tersebut, menulis memang harus melalui proses belajar dan berlatih. Semakin sering belajar dan berlatih, tentu semakin cepat terampil. Seseorang yang sudah biasa menuliskan sebuah ide, gagasan, pendapat, atau perasaannya, maka dia tidak akan mengalami kesulitan berarti ketika harus menulis.

Berdasarkan pengamatan awal pada siswa VII ${ }^{\mathrm{A}}$ SMP Negeri 3 Gorontalo, diperoleh informasi bahwa sebanyak 27 siswa, terdapat 10 orang atau 37,04\% yang telah memiliki keterampilan tersebut. Sisanya 17 orang atau $62,96 \%$ masih belum memiliki keterampilan menulis puisi rakyat berupa pantun. Oleh karena itu, perlu dicari jalan keluar untuk memecahkan beberapa permasalahan tersebut.

Salah satu alternatif solusi inovasi yang peneliti lakukan yaitu dengan mengkolaborasikan antara model pembelajaran dan media pembelajaran yang dikemas dalam PAMPER (Picture And Picture Media Gambar). Model ini dapat menggugah siswa dalam berekspresi yang dituangkan dalam puisi rakyat, dengan cara siswa mengamati suatu gambar yang menarik. Artinya model ini mengajak siswa untuk mengamati sebuah kumpulan gambar, kemudian diekspresikan dengan menggunakan kata-kata dan kalimat yang dituangkan dalam sebuah puisi sehingga akan menjadi lebih mudah dalam menulis puisi rakyat dan mengekspresikan perasaannya setelah mengamati sekumpulan gambar.

\section{TINJAUAN PUSTAKA}

\section{Hakikat Keterampilan Berbahasa}

Terkait dengan hal tersebut, Tarigan (dalam Doyin dan Wagiran 2009:11). Menyimak, berbicara, membaca, dan menulis, merupakan bentuk kompetensi berbahasa. Setiap keterampilan bahasa erat sekali hubungannya dengan tiga keterampilan yang lainnya sehingga disebut catur tunggal (Dawson,dalam Tarigan, 2003:14) Sebagai contoh, orang tidak akan dapat berbicara kalau tidak dapat menyimak.Demikian pula, orang tidak akan dapat menulis tanpa terlebih dahulu dapat membaca. Keterampilan berbicara dan menulis sebagai keterampilan yang produktif didukung oleh keterampilan menyimak dan membaca sebagai keterampilan yang reseptif. Keterampilan menyimak seseorang akan berkembang dengan baik jika didukung oleh keterampilan membaca yang baik pula.

\section{Hakikat Keterampilan Menulis Puisi Rakyat Definisi Puisi Rakyat}

Waluyo (2003:1) puisi adalah karya sastra yang dipadatkan, dipersingkat, dan diberi irama dengan bunyi yang padu dan pemilihan kata-kata kias (imajinatif). Katakata betul-betul dipilih agar memiliki kekuatan pengucapan. Walaupun singkat atau padat, namun berkekuatan. Karena itu, salah satu usaha penyair adalah memilih katakata yang memiliki persamaan bunyi (rima). Katakata itu mewakili kata-kata yang lebih luas dan lebih banyak. Puisi adalah hasil pengungkapan kembali segala peristiwa atau kejadian yang terdapat di dalam kehidupan sehari-hari (Pradopo, 2007:12).

54 AKSARA Jurnal Ilmu Pendidikan Nonformal 


\section{Hakikat Model PAMPER (Picture and Picture Media Gambar)}

Media berasal dari bahasa Latin medius yang secara harfiah berarti ,tengah ${ }^{\text {ee }}$ "perantara"e, atau ,pengantar". Dalam bahasa Arab, media adalah perantara atau pengantar pesan dari pengirim kepada penerima pesan. Arsyad (2003:4) menyatakan bahwa media adalah alat yang menyampaikan atau mengantarkan pesan-pesan pengajaran. Heinich dkk. Dalam Arsyad (2003:4) mengemukakan istilah media sebagai perantara yang mengantar informasi antara sumber dan penerima.

Berdasarkan pendapat para ahli tersebut, maka dapat disimpulkan bahwa media adalah pe-rantara atau pengantar pesan dari sumber informasi kepada penerima pesan. Apabila media membawa pesan-pesan atau informasi yang bertujuan instruksional atau mengandung maksud-maksud pengajaran maka media itu disebut. media pengajaran atau media pembelajaran. Suatu proses pembelajaran bisa terlaksana dengan efektif dan efisien apabila media pembelajaran yang dipakai sesuai dengan materi pembelajaran, sehingga dapat menumbuhkan minat siswa (dialog dan mental siswa). Sehingga terjadi pula komunikasi timbal balik antara media (penyalur pesan) guru dengan siswa. Jadi pengertian media pembelajaran adalah penyalur pesan antara bahan ajar dalam proses pembelajaran berupa unsur peralatan/perangkat keras (hardware) dan unsur pesan (massage) atau perangkat lunak (software).

Terkait dengan hal tersebut, Depdiknas 2003 (dalam Hairudin2007:7.3) mengemukakan bahwa media pembelajaran adalah alat yang digunakan untuk memperagakan fakta, konsep, prosedur tertentu agar lebih konkrit/nyata, mudah dalam mengajar untuk mencapai tujuan pembelajaran. Gagne dan Brigs dikutip Arsyad (2003:4) menyatakan bahwa media pembelajaran meliputi alat yang secara fisik digunakan untuk mencapai materi pembelajaran. Kedudukan media pengajar sebagai alat bantu mengajar ada dalam komponen metodologi pengajaran, sebagai salah satu lingkungan belajar yang diatur oleh guru (Sudjana, 2009:1).

\section{METODE PENELITIAN}

Penelitian ini di laksanakan di kelas VIIA SMP Negeri 3 Gorontalo Kota Gorontalo. Waktu penelitian dilakukan dari bulan September sampai November tahun 2017. Penelitian ini dilaksanakan di kelas VIIA SMP Negeri 3 Gorontalo pada semester Genap tahun pelajaran 2017/2018 yang berjumlah 27 orang siswa yaitu.

Variabel input dalam penelitian ini adalah hasil observasi awal tentang rendahnya keterampilan menulis puisi rakyat sebelum menggunakan Model PAMPER (Picture And Picture Media Gambar), RPP, lembar pengamatan guru dan siswa.

Variabel proses dalam penelitian ini yaitu menyangkut proses pelaksanaan pembelajaran menulis siswa berupa keterampilan menulis puisi rakyat melalui Model PAMPER (Picture And Picture Media Gambar).

Variabel output, Variabel output dalam penelitian ini berupa peningkatan keterampilan menulis puisi rakyat di di kelas VII ${ }^{\mathrm{A}}$ SMP Negeri 3 Gorontalo seperti rasa ingin tahu siswa, keterampilan siswa dan hasil belajar siswa. 
Prosedur penelitian tindakan kelas terdiri atas 4 langkah yaitu (1) Persiapan, (2) Pelaksanaan, (3) Pengamatan, dan (4) Analisis dan Refleksi.

Untuk mendapatkan data yang konkrit penulis menggunakan teknik pengumpulan data dengan cara observasi, Tes, Dokumentasi.

a. Analisis kualitatif tentang kualitas guru melaksanakan proses pembelajaran

b. Analisis kualitatif tentang aktivitas siswa selama menjalani proses pembelajaran

c. Analisis kuantitatif tentang Meningkatkan Keterampilan Menulis Puisi Rakyat dengan mengacu persentase siswa yang tuntas, atau mencapai indikator yang ditentukan yaitu 80 .

\section{HASIL PENELITIAN DAN PEMBAHASAN}

Berdasarkan hasil observasi awal pada hari senin tanggal 11 September 2017 yang dilakukan oleh peneliti di kelas VII ${ }^{\mathrm{A}}$ SMP Negeri 3 Gorontalo, bahwa keterampilan menulis puisi rakyat melalui model PAMPER (Picture And Picture Media Gambar) masih sagat rendah. Hal ini dapat dilihat dari data keterampilan menulis siswa pada tabel berikut:

Tabel 1. Hasil Pengamatan Belajar Siswa pada Pada Observasi Awal

\begin{tabular}{|c|c|c|c|c|c|c|c|}
\hline \multirow{3}{*}{ No. } & \multirow{3}{*}{ Kualifikasi } & \multicolumn{6}{|c|}{ Aspek yang Diamati } \\
\hline & & \multicolumn{2}{|c|}{ Penentuan Tema } & \multicolumn{2}{|c|}{$\begin{array}{l}\text { Pengumpulan } \\
\text { kosakata }\end{array}$} & \multicolumn{2}{|c|}{$\begin{array}{l}\text { Teknik } \\
\text { Penulisan }\end{array}$} \\
\hline & & Jumlah & $\%$ & Jumlah & $\%$ & Jumlah & $\%$ \\
\hline 1 & Terampil & 10 & 37,04 & 10 & 37,04 & 10 & 37,04 \\
\hline 2 & $\begin{array}{l}\text { Kurang } \\
\text { Terampil }\end{array}$ & 17 & $62,96 \%$ & 17 & $62,96 \%$ & 17 & $62,96 \%$ \\
\hline 3 & $\begin{array}{l}\text { Belum } \\
\text { Terampil }\end{array}$ & 0 & 0 & 0 & 0 & 0 & 0 \\
\hline \multicolumn{2}{|c|}{ Jumlah } & 27 & 100 & 27 & 100 & 27 & 100 \\
\hline
\end{tabular}

Berdasarkan pengamatan observasi awal yang dilaksanakan oleh guru mitra dengan memperhatikan data hasil kegiatan belajar pada observasi awal sebagaimana tercantum pada tabel 1 tersebut, menunjukan bahwa pengelolaan belajar yang dilaksanakan guru belum memenuhi indikator pencapaian yang diharapkan..

\section{Hasil Tindakan siklus I}

Berdasarkan hasil tindakan kelas pada siklus I tentang keterampilan menulis puisi rakyat dikelas VII ${ }^{\mathrm{A}}$ SMP Negeri 3 Gorontalo maka diperoleh data sebagai berikut :

Tabel 2. Hasil Pengamatan Keterampilan Menulis Puisi Rakyat Melalui PAMPER (Picture And Picture Media Gambar) Pada siklus I

\begin{tabular}{||l|l|l||}
\hline \hline No. & Kualifikasi & Aspek yang Diamati \\
\hline
\end{tabular}




\begin{tabular}{|c|c|c|c|c|c|c|c|}
\hline & & \multicolumn{2}{|c|}{$\begin{array}{l}\text { Penentuan } \\
\text { Tema }\end{array}$} & \multicolumn{2}{|c|}{$\begin{array}{l}\text { Pengumpulan } \\
\text { kosakata }\end{array}$} & \multicolumn{2}{|c|}{$\begin{array}{l}\text { Teknik } \\
\text { Penulisan }\end{array}$} \\
\hline & & Jumlah & $\%$ & Jumlah & $\%$ & Jumlah & $\%$ \\
\hline 1 & Terampil & 16 & 59,26 & 15 & 55,56 & 18 & 66,67 \\
\hline 2 & $\begin{array}{l}\text { Kurang } \\
\text { Terampil }\end{array}$ & 11 & 40,74 & 12 & 44,44 & 9 & 33,33 \\
\hline 3 & $\begin{array}{l}\text { Belum } \\
\text { Terampil }\end{array}$ & 0 & 0 & 0 & 0 & 0 & 0 \\
\hline \multicolumn{2}{|c|}{ Jumlah } & 27 & 100 & 27 & 100 & 27 & 100 \\
\hline
\end{tabular}

berikut ini:

Untuk Persentase kategori nilai dari hasil evaluasi siklus I disajikan dalam tabel

Tabel 3 Persentase Nilai Hasil Evaluasi Siklus I

\begin{tabular}{|l|l|l|l|}
\hline Nilai & Kriteria & Frekuensi & Persentase (\%) \\
\hline 90 & Sangat Baik & 10 & 37.04 \\
\hline 80 & Baik & 6 & 22.22 \\
\hline 70 & Cukup & 6 & 22.22 \\
\hline 60 & Kurang & 5 & 18.52 \\
\hline Jumlah & & $\mathbf{2 7}$ & $\mathbf{1 0 0}$ \\
\hline
\end{tabular}

Dari tabel di atas terlihat bahwa ada $10(37.04 \%)$ siswa yang memperoleh nilai sangat baik. Siswa yang mencapai baik ada $6(22.22 \%)$. Ada $6(22.22 \%)$ siswa memperoleh nilai cukup. Sejumlah 5 (18.52\%) siswa memperoleh nilai kurang Jika disajikan dalam diagram batang adalah sebagai berikut:

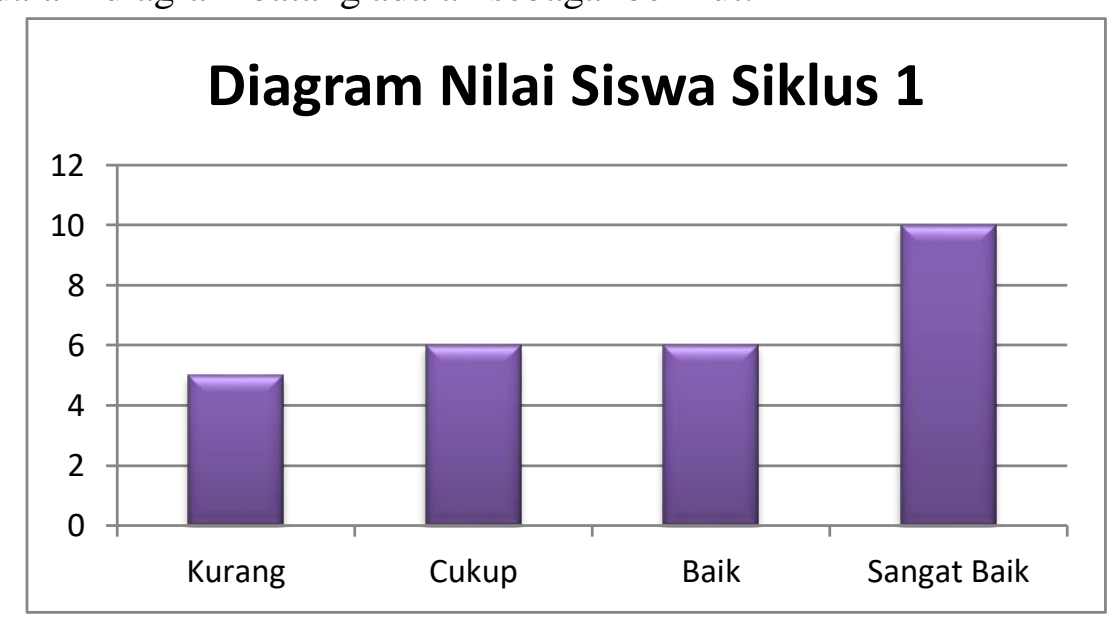

\section{Refleksi Siklus I}

Refleksi dilakukan dengan kolabolator, guru mitra yang bertindak selaku pengamat dalam proses belajar mengajar. Refleksi dimaksudkan untuk memperoleh gambaran apakah tindakan yang dilaksanakan telah sesuai dengan apa yang 
diharapkan, dalam hal ini meningkatkan keterampilan menulis puisi rakyat melalui model PAMPER (Picture And Picture Media Gambar) di kelas VII ${ }^{\mathrm{A}}$ SMP Negeri 3 Gorontalo.

\section{Hasil Tindakan Siklus II}

Dari hasil pengamatan yang dilakukan diketahui bahwa perkembangan keterampilan menulis puisi rakyat melalui model PAMPER (Picture And Picture Media Gambar) di kelas VII ${ }^{\mathrm{A}}$ lebih meningkat dibandingkan dari siklus I. Dari hasil pelaksanaan siklus II, maka diperoleh data sebagai berikut :

Tabel 5. Hasil Pengamatan keterampilan menulis puisi rakyat melalui model PAMPER (Picture And Picture Media Gambar) di kelas VII ${ }^{\mathrm{A}}$ Pada Siklus II

\begin{tabular}{|c|c|c|c|c|c|c|c|}
\hline \multirow{3}{*}{ No. } & \multirow{3}{*}{ Kualifikasi } & \multicolumn{6}{|c|}{ Aspek yang Diamati } \\
\hline & & \multicolumn{2}{|c|}{$\begin{array}{l}\text { Penentuan } \\
\text { Tema }\end{array}$} & \multicolumn{2}{|c|}{$\begin{array}{l}\text { Pengumpulan } \\
\text { kosakata }\end{array}$} & \multicolumn{2}{|c|}{$\begin{array}{l}\text { Teknik } \\
\text { Penulisan }\end{array}$} \\
\hline & & Jumlah & $\%$ & Jumlah & $\%$ & Jumlah & $\%$ \\
\hline 1 & Terampil & 25 & 92,59 & 26 & 96.30 & 24 & 88.89 \\
\hline 2 & $\begin{array}{l}\text { Kurang } \\
\text { Terampil }\end{array}$ & 2 & 7.41 & 1 & 3.70 & 3 & 11.11 \\
\hline 3 & $\begin{array}{l}\text { Belum } \\
\text { Terampil }\end{array}$ & 0 & 0 & 0 & 0 & 0 & 0 \\
\hline \multicolumn{2}{|c|}{ Jumlah } & 27 & 100 & 27 & 100 & 27 & 100 \\
\hline
\end{tabular}

Berdasarkan pengamatan yang dilaksanakan oleh guru mitra dengan memperhatikan data hasil kegiatan belajar pada siklus II sebagaimana tercantum dalam tabel 5 tersebut menunjukan bahwa pengelolaan pembelajaran yang dilaksanakan guru telah memenuhi indikator pencapaian yang diharapkan.

Dari hasil tabel siklus II di atas dapat terlihat bahwa dari 27 orang siswa terdapat 25 orang siswa atau $92,59 \%$ yang terampil, dan 2 orang siswa atau $7.41 \%$ yang kurang terampil. Kemudian pada aspek pengumpulan kosakata dari 27 orang siswa terdapat 26 orang siswa atau $96.30 \%$ yang terampil, dan 1 orang siswa atau $3.70 \%$ yang kurang terampil. Selanjutnya pada aspek penilaian teknik penulisan terdapat 24 orang atau $88.89 \%$ yang terampil dan sisanya 3 orang atau $11.11 \%$ yang belum terampil.

Untuk Persentase kategori nilai dari hasil evaluasi siklus I disajikan dalam tabel berikut ini:

Tabel 6 Persentase Nilai Hasil Evaluasi Siklus II

\begin{tabular}{|l|l|l|l|}
\hline Nilai & Kriteria & Frekuensi & Persentase (\%) \\
\hline 90 & Sangat Baik & 20 & 74.07 \\
\hline 80 & Baik & 5 & 18.52 \\
\hline 70 & Cukup & 2 & 7.41 \\
\hline
\end{tabular}

58 AKSARA Jurnal Ilmu Pendidikan Nonformal 


\section{Jumlah} 27 100

Dari tabel di atas terlihat bahwa ada 20 (74.07\%) siswa yang memperoleh nilai sangat baik. Siswa yang mencapai baik ada $5(18.52 \%)$. Ada $2(7.41 \%)$ siswa memperoleh nilai cukup. Jika disajikan dalam diagram batang adalah sebagai ber

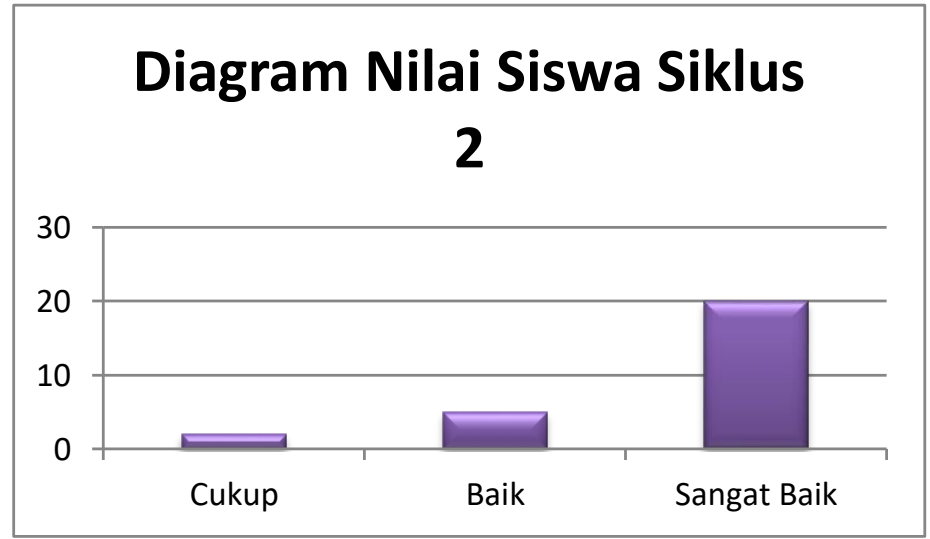

\section{Refleksi Siklus II}

Kegiatan refleksi dilaksanakan melalui diskusi dengan guru pengamat. Refleksi ini dilakukan untuk meninjau kembali target yang hendak dicapai yang telah diperoleh. Berdasarkan evaluasi proses dan hasil tindakan sebagaimana yang telah dikemukakan pada bagian terdahulu, maka dapat disimpulkan bahwa hasil yang diperoleh pada siklus II telah menunjukkan adanya peningkatan yang sangat signifikan dibandingkan hasil yang diperoleh pada siklus 1 .

Bahkan berdasarkan hasil penilaian guru pengamat menyatakan bahwa proses pembelajaran telah terlaksana dengan baik dan berhasil. Menurut data penilaian yang diberikan oleh guru pengamat menunjukkan bahwa kegiatan pembelajaran tentang kemampuan berbicara dalam penggunaan diksi melalui model artikulasi yang dilaksanakan guru berlangsung sesuai rencana dan memperoleh hasil sesuai dengan kriteria yang telah ditetapkan. Sehingga dapat disimpulkan bahwa kegiatan pembelajaran telah terlaksana dengan memperoleh hasil yang sangat memuaskan serta tidak perlu lagi ada tindakan siklus berikutnya.

\section{Pembahasan}

Mata pelajaran bahasa Indonesia merupakan salah satu mata pelajaran umum yang diajarkan di SMP Negeri 3 Gorontalo dan khususnya di kelas VII ${ }^{\mathrm{A}}$. Pada mata pelajaran bahasa Indonesia, siswa dituntut untuk menguasai aspek-aspek kemampuan berbahasa yakni, aspek menyimak/mendengarkan, aspek berbicara, aspek membaca, dan aspek menulis. Salah satu aspek kemampuan yang dipelajari di SMPNegeri 3 Gorontalo kelas VII ${ }^{\mathrm{A}}$ adalah aspek menulis. Konsep materi yang diberikan dalam pelaksanaan Penelitian Tindakan Kelas ini adalah Keterampilan Menulis Puisi Rakyat 


$\begin{array}{ll}\text { Volume } & : 05 \\ \text { Nomor } & : 01 \\ \text { Bulan } & : \text { Januari } \\ \text { Tahun } & : 2019 \\ \text { http } & : \text { //ejurnal.pps.ung.ac.id/index.php/AKSARA/index }\end{array}$

Melalui Model PAMPER (Picture And Picture Media Gambar). Dengan pengguaan model tersebut siswa diharapkan mampu untuk belajar aktif dalam mengikuti pelajaran. Dengan memperhatikan keterampilan siswa dalam menulis puisi rakyat melalui model PAMPER (Picture And Picture Media Gambar) yang diperoleh dari siklus I dapat terlihat bahwa aspek penentuan tema dari 27 orang siswa hanya terdapat 16 orang siswa atau 59,26\% yang terampil, dan 11 orang siswa atau 40,74\% yang kurang terampil. Kemudian pada aspek pengumpulan kosakata dari 27 orang siswa hanya terdapat 15 orang siswa atau 55,56\% yang terampil, dan 12 orang siswa atau 44,44\% yang kurang terampil. Selanjutnya pada aspek penilaian teknik penulisan terdapat 18 orang atau $66,67 \%$ yang terampil dan sisanya 9 orang atau 33, 33\% yang belum terampil.

Pada aspek penilaian tes kognitif terlihat bahwa ada $10(37.04 \%)$ siswa yang memperoleh nilai sangat baik. Siswa yang mencapai baik ada 6 (22.22\%). Ada 6 (22.22\%) siswa memperoleh nilai cukup. Sejumlah 5 (18.52\%) siswa memperoleh nilai kurang

Pada data hasil siklus II terlihat juga bahwa bahwa dari 27 orang siswa terdapat 25 orang siswa atau 92,59\% yang terampil, dan 2 orang siswa atau $7.41 \%$ yang kurang terampil. Kemudian pada aspek pengumpulan kosakata dari 27 orang siswa terdapat 26 orang siswa atau $96.30 \%$ yang terampil, dan 1 orang siswa atau $3.70 \%$ yang kurang terampil. Selanjutnya pada aspek penilaian teknik penulisan terdapat 24 orang atau $88.89 \%$ yang terampil dan sisanya 3 orang atau $11.11 \%$ yang belum terampil.

\section{PENUTUP}

Berdasarkan hasil penelitian dan pembahasan, maka dapat dikemukakan kesimpulan bahwa terjadi peningkatan bahwa keterampilan menulis puisi rakyat melalui model PAMPER (Picture And Picture Media Gambar) di kelas VII ${ }^{\mathrm{A}}$ SMP Negeri 3 Gorontalo, yakin:

1. Dari jumlah 27 orang siswa yang dikenakan tindakan pada siklus I terlihat bahwa pada aspek penentuan tema dari 27 orang siswa hanya terdapat 16 orang siswa atau $59,26 \%$ yang terampil. Sedangkan pada siklus II terjadi peningkatan yakni 25 orang siswa atau $92,59 \%$ yang terampil.

2. Dari jumlah 27 orang siswa yang dikenakan tindakan pada siklus I terlihat bahwa pada aspek pengumpulan kosakata terdapat 15 orang siswa atau 55,56\% yang terampil. Sedangkan pada siklus II terjadi peningkatan yakni 26 orang siswa atau $96.30 \%$ yang terampil.

3. Dari jumlah 27 orang siswa yang dikenakan tindakan pada siklus I terlihat bahwa pada aspek penilaian teknik penulisan terdapat 18 orang atau 66,67\% yang terampil. Sedangkan pada siklus II terjadi peningkatan yakni 24 orang atau $88.89 \%$ yang terampil.

Berdasarkan hasil penjelasan 3 point tersebut, maka dapat disimpulkan bahwa penggunaan model PAMPER (Picture And Picture Media Gambar) dapat meningkatkan keterampilan siswa dalam menulis puisi rakyat, sehingga model pembelajaran ini menjadi acuan dalam meningkatkan kemampuan menulis siswa.

60 AKSARA Jurnal Ilmu Pendidikan Nonformal 


$\begin{array}{ll}\text { Volume } & : 05 \\ \text { Nomor } & : 01 \\ \text { Bulan } & : \text { Januari } \\ \text { Tahun } & : 2019 \\ \text { http } & : \text { //ejurnal.pps.ung.ac.id/index.php/AKSARA/index }\end{array}$

\section{DAFTAR PUSTAKA}

Aminuddin. 2009. Pengantar Apresiasi Karya Sastra. Bandung:Sinar Baru Algesindo.

Arsyad, Azhar. 2004. Media Pembelajaran. Jakarta:Raja Grafindo Persada.

Bastra Yoman.2012. Hakikat Puisi Rakyat dan Ciri-cirinya dalam perspektif budaya. http://yomanbastra.blogspot.co.id/2012/06/hakikat-puisi-lama.html Akses tanggal 12 Oktober 2017

Depdiknas. 2003. Kurikulum 2004 Sekolah Dasar Mata Pelajaran Bahasa Indonesia.

Eko Sugiarto. (2012). Pantun dan Puisi Lama Melayu. Yogyakarta: Kithah Publishing.

Joko Santoso. 2013. Buku Pintar Pantun, Puisi Lama Melayu dan Peribahasa Indonesia. Yogyakarta: Araska.

Pradopo, Rachmad Djoko. 2007. Pengkajian Puisi. Yogyakarta:Gadjah Mada University Press.

Rahayu, Minto. 2007. Bahasa Indonesia di Perguruan Tinggi. Jakarta:Grasindo

Sutedjo dan Kasnadi, 2008, Menulis Kreatif: Kiat Cepat Menulis Puisi dan Cerpen. Yogyakarta: Nadi Pustaka.

Sudjana, Nana, dan Ahmad Rivai. 2009. Media Pengajaran. Bandung:Sinar Baru Algesindo.

Suharsimi Arikunto. (2006). Prosedur Penelitian Suatu Pendekatan Praktek. Jakarta: Rineka Cipta.

Tarigan, Djago.dkk. 2003. Pendidikan Keterampilan Berbahasa. Jakarta:UT.

Waluyo, Herman J. 2003. Apresiasi Puisi Panduan Untuk Pelajar dan Mahasiswa.Jakarta:Gramedia Pustaka Utama.

Wendi Widya R. D. (2008). Bedah Puisi Lama. Klaten: Intan Pariwara. 
Volume : 05

Nomor : 01

Bulan : Januari

Tahun : 2019

http : //ejurnal.pps.ung.ac.id/index.php/AKSARA/index

62 AKSARA Jurnal Ilmu Pendidikan Nonformal 